$\begin{array}{lll}\text { KULTURA } & \begin{array}{l}\text { POLSKA A KADEMIA NAUK } \\ \text { KOMITET SOCJOLOGII }\end{array} & \text { ISSN 0023-5172 } \\ \text { I } & \begin{array}{l}\text { INSTYTUT STUDIÓW POLITYCZNYCH } \\ \text { SPOLECLENSTWO nr } 2 \quad \text { MIASTO }\end{array} & \\ \end{array}$

MAGDALENA MOSTOWSKA

Uniwersytet Warszawski

\title{
CODZIENNOŚĆ WOKÓŁ SKUPÓW ZŁOMU W WARSZAWIE*
}

\section{PRZEDMIOT BADAŃ}

Grzebiący w śmietnikach oraz złomiarze pchający wózki ulicami polskich miast to - obok górników zwolnionych z kopalni i pracujących w biedaszybach (Rakowski 2007) czy bezczynnych pracowników upadłych PGR-ów - osoby przywoływane jako symbol rozwarstwienia społeczeństwa polskiego po upadku komunizmu i kosztów transformacji społeczno-ekonomicznej.

W wielu kulturach zajmowanie się śmieciami, odpadami i nieczystościami wiąże się ze stygmatyzacją. Pochylanie się po to, co porzucili inni, postrzegane jest nie tylko jako przejaw nędzy, ale też jako utrata godności. W poszczególnych krajach różne grupy zepchnięte są na ten najniższy poziom hierarchii społecznej. W miastach tzw. Trzeciego Świata wysypiska śmieci przeszukiwane są najczęściej przez młode kobiety z rodziną na utrzymaniu i bez dochodu (Tevera 1994; Adeyemi i in. 2001). W badaniach amerykańskich waste scavenging to wyodrębniona kategoria wśród metod zarabiania „na ulicy”, dotyczy na ogół pojedynczych „meneli”, bezdomnych mężczyzn (bums) (Hill, Stamey 1990). W literaturze na temat biedy w Polsce „zbieractwo miejskie” pojawia się jako skutek marginalizacji i sposób zarobkowania poza rynkiem pracy (Golinowska i in. 2007) oraz strategia przetrwania wielu osób bezdomnych (Nóżka 2006).

Indywidualni klienci skupów złomu to zróżnicowana grupa. Metale sprzedaje wiele osób, które $z$ racji swojej pracy mają dostęp do takich odpadów - budowlańcy, hydraulicy, mechanicy, dozorcy, sprzątacze, śmieciarze. Prasa donosi o przypadkach masowych kradzieży, niekiedy dokonywanych przez dobrze zorganizowane i wyposażone gangi złodziei, które tną na kawałki i kradną szyny kolejowe, ściągają ciągnikami kable trakcji elektrycznej itd. Na mniej-

Adres do korespondencji: Instytut Studiów Regionalnych i Globalnych Wydziału Geografii i Studiów Regionalnych UW, ul. Karowa 20, 00-324 Warszawa; mmostowska@gazeta.pl

${ }^{*}$ Wcześniejsza wersja tego tekstu została przygotowana w ramach zajęć z Metod Badań Niesondażowych w Instytucie Socjologii UW pod kierunkiem Sylwii Urbańskiej. 
szą skalę złodzieje kradną pomniki, nagrobki z cmentarzy, kable telefoniczne, ogrodzenia czy pokrywy studzienek kanalizacyjnych. Opłacalna jest w szczególności sprzedaż miedzi (13-17 zł/kg), która w większości pochodzi z kradzieży (opalanych kabli telekomunikacyjnych). Pojedynczy złomiarze uprawiający ten proceder potrafią zarobić wystarczająco, by utrzymać mieszkanie, rodzinę i żyć na poziomie nie odbiegającym od przeciętnej, ale muszą „kalkulować ryzyko”.

Najniżej w hierarchii osiągających dochody ze zbieractwa stoją „nurkowie”, czyli osoby grzebiące w śmietnikach; ci, którzy zbierają puszki, wszelkie wyrzucone elementy metalowe - żaluzje, rury, grzejniki, sprzęty kuchenne, pralki, lodówki - a także makulaturę, butelki i inne przedmioty na własny użytek, na wymianę bądź na sprzedaż. Zbieractwo, poza drobnymi kradzieżami, wyłudzeniami i żebraniem, jest właściwie ich jedynym źródłem dochodu — od kilku do kilkunastu złotych dziennie, sporadycznie jakieś znalezisko może przynieść kilkadziesiąt złotych. Nurkowie to przede wszystkim bezrobotni i uzależnieni od alkoholu mężczyźni w średnim i starszym wieku; na ogół bezdomni, zaniedbani fizycznie, często $z$ widocznymi ułomnościami, nierzadko chorzy psychicznie.

Oszacowanie liczby bezdomnych żyjących w Warszawie ze zbieractwa jest trudne. Badanie osób bezdomnych przebywających w noclegowniach i schroniskach w 2005 r. wykazało, że 13\% spośród nich trudniło się zbieractwem (Sytuacja... 2005, s. 24). Skądinąd wiadomo, że zbieractwem zajmują się głównie bezdomni nie przebywający w schroniskach i wiele osób ubogich, ale nie bezdomnych (Golinowska i in. 2007). Tylko na Ursynowie Justyna Kaźmierczak (2005, s. 6) szacuje liczbę „stałych” zbieraczy na około stu. W dwustutysięcznych Kielcach mówi się o około trzystu złomiarzach (Potocka 2004). W Warszawie liczbę bezdomnych szacuje się nawet na około 10 tysięcy. Skupów złomu i makulatury działa obecnie w stolicy co najmniej kilkadziesiąt. Do obserwowanych przeze mnie punktów w ciągu godziny przychodziło od 20 do 100 osób. Nawet najostrożniejsze szacunki prowadzą więc do określenia populacji osób trudniących się zbieractwem w Warszawie na parę tysięcy.

\section{DOTYCHCZASOWE ROZPOZNANIE PROBLEMU}

Istnieje bogata literatura na temat biedy w polskich miastach, jednak w kontekście tej problematyki jedynie niepublikowany tekst Justyny Kaźmierczak (2005) zawiera opis osób żyjących ze zbieractwa w Warszawie. Prace Tomasza Rakowskiego (2007) dotyczą zupełnie odmiennego kontekstu Wałbrzycha. Zbieractwo pojawia się natomiast w literaturze na temat bezdomności. Spory o definicję bezdomności wynikają z ogromnego zróżnicowania tej populacji. Często stosowany jest podział na bezdomnych „pozaschroniskowych” i „schroniskowych", czy też zinstytucjonalizowanych. Ci ostatni cechować się mogą biernością, wyuczoną bezradnością i postawą roszczeniową (Oliwa-Ciesielska 2006). Marcjanna Nóżka (2006, s. 104 i nast.) tej grupie bezdomnych, pragnących stabilizacji, przeciwstawia bezdomnych „z wyboru”, którzy uważają 
się za niezależnych i zaradnych, którzy nie szukają pomocy instytucjonalnej, łączy ich zaś włóczęgostwo. Wśród tych mobilnych bezdomnych Nóżka wyróżnia dwa typy: „gigantów” i „łaziorów”. To właśnie przede wszystkim „łaziory” trudnią się miejskim zbieractwem. Są to na ogół zaniedbani, uzależnieni od alkoholu mężczyźni z charakterystycznymi atrybutami przeszukiwaczy śmietników (Nóżka 2006, s. 107 i nast.). Podobną typologię bezdomnych w nieopublikowanej pracy magisterskiej zaproponowal Piotr Wachowiak (1998; zob. Przymieński 2001, s. 174 i nast.). Wyróżnił on „gigantów”, „nurów” i „penerów”. „Nurowie” prowadzą, jego zdaniem, osiadły tryby życia, są samotni, zaniedbani, uzależnieni od alkoholu i żyją ze zbieractwa. W dotychczasowej literaturze przedmiotu brakuje, moim zdaniem, badań skupiających się na obserwacji grup w miejscu ich codziennych aktywności, na bezpośrednim opisie strategii zdobywania środków do życia, spędzania czasu, konsumpcji, zawłaszczania pewnych miejsc $\mathrm{w}$ przestrzeni miasta, kontaktów towarzyskich czy relacji z szerszym otoczeniem.

Z moich obserwacji i reportaży prasowych wynika, że nurkowie są na ogół wierni jednej dzielnicy czy obszarowi miasta, jednemu skupowi, na ogół mają stałą „trasę”. Skup jest zatem bardzo ważnym miejscem w codziennych doświadczeniach tych osób. Oczywiście poza pracą (w samotności, z partnerką lub ze wspólnikiem) nurkowie należą do szerszych grup, mają znajomych $\mathrm{w}$ miejscu zamieszkania (jeżeli są bezdomni, to $\mathrm{w}$ znanych sobie miejscach, na działkach, w pustostanach, noclegowniach). Takie sieci powiązań w kontekście przestrzennym dają poczucie bezpieczeństwa, pewien rodzaj kapitału społecznego, poczucie przynależności i własnej wartości. Wskazuje się, że bezdomność szczególnie destrukcyjnie wpływa na ten rodzaj więzi. Dlatego dla osób bezdomnych (i w związku z tym na ogół bezrobotnych), które doświadczają czasowo-przestrzennej nieciągłości (time-space discontinuity) szczególnie ważne stają się pewne miejsca na ich codziennych ścieżkach (daily-paths) (Rowe, Wolch 1990, s. 184). W poniższym opisie skupię się na pewnej grupie warszawskich nurków, na jej wewnętrznej strukturze oraz interakcjach z otoczeniem.

\section{CEL, CHARAKTER I METODOLOGIA BADANIA}

Badanie inspirowane było monografiami miejskich społeczności zakorzenionymi w tradycji chicagowskiej, w których przyjmowano przede wszystkim perspektywę mikrosocjologiczną. W tym podejściu społeczeństwo nie składa się ze struktur czy instytucji, a miasto $z$ bezosobowych interakcji, lecz $z$ istniejących realnie grup. I to właśnie sieci powiązań, spotkania, interakcje, przyjmowanie ról, komunikacja, które wraz z kontekstem przestrzennym wytwarzają wspólne doświadczenia i przedstawienia zbiorowe są przedmiotem badania (Wódz 1992, s. 87). Zastosowane metody badawcze zaś to: obserwacja uczestnicząca i rozmowy swobodne. 
Celem mojego badania był przede wszystkim opis codzienności, kontaktów i interakcji między osobami trudniącymi się zbieraniem surowców wtórnych i sprzedawaniem ich w skupach w Warszawie. Badanie miało charakter eksploracyjny, wszelkie wnioski wyciągnięte z obserwacji dotyczą tylko obserwowanej grupy, a i te należy traktować jako wstępne i wymagające weryfikacji. Badanie ograniczyło się bowiem do obserwacji uczestniczącej i rozmów podczas niecałych trzech miesięcy.

Skupy makulatury i złomu znajdują się na ogół na obrzeżach miasta, często skupują towar od zakładów, mechaników, budowlańców. Te bliżej śródmieścia nastawione są na klientów indywidualnych $\mathrm{Z}$ kilku odwiedzonych wcześniej skupów w Warszawie ostatecznie wybrałam do obserwacji dwa sąsiadujące ze sobą punkty - istniejący tam od dawna i "nowy” — na niewielkiej zaniedbanej uliczce, przecznicy jednej z głównych arterii miasta, otoczonej wieloma sklepami i zróżnicowaną zabudową mieszkaniową, prawie w centrum miasta. Od 30 marca do 15 czerwca 2008 r. spędziłam tam w sumie około 24 godzin. $\mathrm{W}$ różnych porach dnia i dniach tygodnia dziewiętnaście razy byłam w terenie. Jednorazowe obserwacje nie były więc długie, parokrotnie musiałam je przerwać ze względu na poczucie zagrożenia. Oprócz obserwacji wokół skupów rozmawiałam także gdzie indziej z paroma nurkami z opisywanej grupy, ze sprzedawcami okolicznych sklepów, mieszkańcami pustostanu oraz z innymi nurkami spotkanymi przypadkowo na ulicy w różnych częściach miasta i kilku innych skupach złomu i makulatury w Warszawie.

W początkowym okresie obserwacja miała charakter mniej uczestniczący, starałam się sprawiać wrażenie przypadkowego przechodnia. Po kilku takich pobytach zaczęłam być rozpoznawana przez stałych bywalców okolicy i moja obserwacja stała się znacznie „bardziej uczestnicząca”, przeplatana wizytami w skupach i rozmowami. Niewątpliwie byłam tam uczestnikiem-outsiderem. Od typowych bywalców odróżniało mnie niemal wszystko - wiek, płeć, wygląd (przede wszystkim ubranie). Wielokrotnie miałam jednak poczucie przynależności do grupy „na murku”, w szczególności wobec osób z zewnątrz.

Mojej obecności w okolicy skupów w żaden sposób nie rejestrowałam na bieżąco. Notatki z obserwacji i rozmów starałam się sporządzać natychmiast po oddaleniu się z miejsca obserwacji. Notatki te wielokrotnie uzupełniałam. Często jednak miałam problemy z odtworzeniem szczegółów dłuższych rozmów, $z$ wieloma osobami, często prowadzonych w dużym napięciu i niekiedy językiem dla mnie obcym.

\section{OMÓWIENIE WYNIKÓW OBSERWACJI}

Obserwacje prowadzone były bez sformułowania specyficznego problemu, dlatego zebrany materiał obejmował bardzo wiele wątków. Przedstawię tu dwie główne kwestie - interakcje wewnątrz grupy i interakcje $z$ osobami spoza grupy - oraz szkicowo nakreślę jedno bardzo interesujące zagadnienie, choć 
tylko w niewielkim stopniu poddane obserwacji — relacje między mężczyznami i kobietami w grupie.

$\mathrm{Na}$ początku chciałabym ogólnie scharakteryzować nurków, czyli osoby w najprostszy sposób zbierające warte odsprzedania śmieci. Jak już pisałam, w przeważającej większości są to bezdomni i uzależnieni od alkoholu mężczyźni. Jednak wśród klientów skupu zaobserwować można także osoby, dla których zbieractwo jest dodatkowym źródłem dochodu, są to przede wszystkim starsze kobiety, widziałam także dwie kobiety z dorosłymi upośledzonymi umysłowo dziećmi; przychodzą również starsi mężczyźni (schludni i, wydaje się, niepijący), młodzież („dresiarze”), a nawet dzieci (dresiarze i dzieci wśród nurków to wyłącznie chłopcy).

Nurkowie pracują samotnie lub w parach (wyjątkiem są dzieci i dresiarze). Pary składają się albo z dwóch mężczyzn, albo z kobiety i mężczyzny (takiej parze nierzadko towarzyszy pies). Różne są metody transportu towaru. Niektórzy używają wózków (na bazie wózków dziecięcych, sklepowych, transportowych, zakupowych na kółkach); ci, którzy zbierają głównie puszki, przynoszą towar w torbach. Dobry wózek jest obiektem zazdrości, a niekiedy kradzieży. Z tego powodu na parę zbieraczy na ogół przypada jeden wózek, wówczas jedna osoba zawsze pilnuje wózka. Wózek jest wzmacniany, reperowany, zostawić go można tylko pod opieką kogoś zaufanego, za drobną opłatą można go komuś użyczyć do przetransportowania niecodziennego, ciężkiego znaleziska. Dobrze wyposażeni nurkowie mają też przeróżne narzędzia, do najprzydatniejszych należą łom i sekator. Najgorzej zaopatrzeni mają zaledwie jakieś narzędzie grzebiące: rączkę parasola, laskę lub wieszak na ubranie.

Głównym towarem zbieranym na sprzedaż są puszki aluminiowe. Cena za kilogram puszek (56 sztuk półlitrowych - zgniecione wyp̣ełniają dwie reklamówki zakupowe) waha się obecnie od 3,5 do 4 złotych. Żeliwo i zwykła stal kosztują od 20 do 50 groszy za kilogram, a więc na przykład ośmiożeberkowy kaloryfer, który waży $60 \mathrm{~kg}$, jest wart około 12 złotych, „rozebrana” (z innych niż stalowe elementy) pralka ważąca $80 \mathrm{~kg}$ - około 30 złotych. Są to jednak znaleziska trudne $\mathrm{w}$ transporcie. Najbardziej opłacalna jest sprzedaż elementów z metali kolorowych - aluminiowe naczynia, żaluzje $(5 \mathrm{zl} / \mathrm{kg})$, zawory z brązu (13 zł/kg), mosiężne okucia, ozdoby (10 zł/kg), chłodnice samochodowe itp. Najniżej sytuowani nurkowie nie gardzą zwykłą makulaturą, której cena to raptem kilkanaście groszy za kilogram. Zbierane są także butelki po piwie, butelki po drogich alkoholach, które można sprzedać $\mathrm{w}$ niektórych skupach, a także na przykład promocyjne nakrętki od butelek po napojach.

W poszukiwaniu „towaru” nurkowie przeszukują przede wszystkim śmietniki osiedlowe. Najlepsze pod względem obfitości i dostępności towaru są osiedla wysokich bloków. Na niewielkiej powierzchni gromadzą się tam odpady kilku, kilkunastu tysięcy mieszkańców, śmietniki są wspólne i na ogół otwarte. 


\section{GRUPA — PODTRZYMYWANIE WIĘZI}

\section{Miejsce}

Skupy są dla nurków miejscem docelowym po wielogodzinnej pracy, także miejscem wypłaty, która może następować nawet parę razy dziennie. Pełnią zatem wiele funkcji. Okolice skupu stają się miejscem odpoczynku, picia, jedzenia, palenia papierosów, wydalania, segregacji towaru, zaopatrywania się w alkohol i papierosy, wymiany towarów znalezionych, miejscem okazjonalnego „zapuszczania wędki”, punktem spotkań i wymiany informacji.

Opisywana przeze mnie grupa nie ma ostro zdefiniowanych granic. $\mathrm{Na}$ pewno należą do niej trzy męsko-damskie pary nurków, kilku nurków samotnych, dwóch mieszkańców pobliskiego pustostanu, ale w spotkaniach uczestniczy także wiele innych osób. Grupa ta okresowo zawłaszcza przestrzeń uliczki. Usytuowanie obserwowanych skupów pozwala grupie zbierać się wokół murku kilkudziesięciocentymetrowej wysokości, na którym można usiąść i który jest także doskonałym punktem obserwacyjnym, pozwalającym na kontrolę tych, którzy skręcają w uliczkę i kierują się do skupów.

„Murek” jest jednak „na widoku”. Dlatego do dokonania szybkiej transakcji lub wypicia na stojąco wykorzystywana jest także przestrzeń po przeciwnej stronie ulicy, miejsce wciśnięte między nieczynny kiosk, budkę telefoniczną i drzewo, względnie niewidoczne dla przechodniów.

Dzięki zajmowaniu tych strategicznych pozycji grupa może kontrolować przybywające na uliczkę osoby. Na chodniku przyległym do murku ta kontrola jest bardziej bezpośrednia, można zostać zaczepionym, popchniętym, ale można się też przywitać, wymienić informacje. Po drugiej stronie ulicy jest się tylko obserwowanym, ewentualnie narażonym na wyzwiska. W rytuałach witania się osób wchodzących na róg ujawniają się konflikty i hierarchia. Niektórzy ograniczają się do skinienia głową, ewentualnie z daleka kurtuazyjnego „cześć” lub „siemanko” (do tej grupy należą wszystkie kobiety). Niektórzy mężczyźni wymieniają uścisk dłoni i parę zdań.

Rząd prostopadłych do uliczki pawilonów handlowo-usługowych także pełni ważne funkcje. Znajduje się tam między innymi hurtownia papierosów i dwa sklepy alkoholowe. Zaplecze pawilonów zapewnia niewidoczną dla przechodniów enklawę, zaśmieconą i zaniedbaną, $z$ bardzo wąskim wejściem kontrolowanym bezpośrednio z murku. Miejsce to służy porzucaniu niepotrzebnych towarów, „rozbieraniu towaru”, na przykład telewizora, lodówki, wymienianiu się towarem nielegalnym, piciu oraz załatwianiu potrzeb fizjologicznych. Drugie takie miejsce to pobliski „parking”, pusta działka, która w dni powszednie pełni funkcję parkingu, ale w jej głębi także znajduje się przestrzeń picia, „rozbierania towaru”, jedzenia i wydalania. Parking jest słabiej kontrolowany przez grupę, łatwiej tam niż za pawilonami być zaskoczonym przez patrol policji. 


\section{Czas}

Podstawowym miernikiem czasu dla nurków są godziny otwarcia skupów. Widać to zwłaszcza wieczorem lub popołudniem w weekendy, kiedy „trzeba zdążyć" przed zamknięciem skupów. Rytm czasu jest wyraźnie zaburzony w dni świąteczne, kiedy to skupy są zamknięte lub otwarte $\mathrm{w}$ godzinach innych niż zazwyczaj. Skupy działają codziennie od 7, 8 rano do popołudnia i wieczora. W niedziele czynny jest tylko „nowy” skup.

W okolicy murku godzinę sprawdza się na ogół na zegarze ściennym, który wisi w kwiaciarni naprzeciwko wejścia, a można go dostrzec również wtedy, gdy kwiaciarnia jest zamknięta. W niedziele i święta czas odmierzany jest także biciem dzwonów na dzwonnicy pobliskiego kościoła oraz rytmem mszy i innych ceremonii. Na ogół jednak znajomość dokładnej godziny nie jest dla nurków ważna, ważniejsze jest dopasowanie do siebie czasowo-przestrzennych cykli różnych osób, o czym piszę poniżej. Stosunek do czasu wyraża się w częstych odpowiedziach na pytanie o godzinę typu: „A na chuja ci to wiedzieć, zrobi się ciemno, pójdziesz spać".

Rytm czasu i sekwencja miejsc zostały przedstawione na rysunku 1. Cykl ten może się powtarzać nawet kilka razy dziennie (niekiedy z pominięciem niektórych elementów), co jest o tyle ważne, że umożliwia wymianę informacji w grupie, spotkania, dopasowanie czasu pojedynczego nurka lub pary do cyklu innych członków grupy. Wejście na róg wiąże się z wypytywaniem o innych znajomych: „Czy był tu Andrzej?”; „Czy widziałeś Cygana?”. Pozwala to zorientować się, w jakim momencie cyklu są pozostałe osoby i ewentualnie na nie poczekać.

Narożnik ulic (wraz z „murkiem”) jest miejscem centralnym, miejscem zbierania się, oczekiwania, ale także wielu wymian i zdarzeń, najlepszym miejscem obserwacji i sprawowania kontroli. Przychodzący „z trasy” nurkowie w zależności od swojej pozycji wobec osób zawłaszczających miejsce wokół murku starają się je albo ominąć, albo przywitać $z$ daleka, albo wejść z nimi w bliższą interakcję. Jeżeli przychodzi para, to tylko jedna osoba $z$ pary delegowana jest „na skup”. Nurek nie należący do grupy, który wychodzi ze skupu, a więc jest „zarobiony”, narażony jest na wyłudzenie części swojego dochodu przez bywalców rogu. W zależności od swojej pozycji albo musi oddać część zarobku, albo naraża się na przemoc, może niekiedy wykupić się przez podzielenie się winem lub papierosami. Jeżeli jest to członek grupy, musi powiedzieć, ile dostal, a następnie rozpoczynają się negocjacje: kto idzie do sklepu, kto ile dorzuca. Picie i palenie odbywa się bezpośrednio wokół murku albo w którejś z przestrzeni mniej widocznych dla przechodniów, czyli za pawilonami albo na parkingu.

Ważnym elementem cyklu jest wymiana innych towarów, może ona następować $\mathrm{w}$ zasadzie $\mathrm{w}$ dowolnym momencie i miejscu. Wymiana dotyczy przede wszystkim przedmiotów znalezionych na śmietnikach (prawdopodobnie też 
Cykl przestrzenno-czasowy

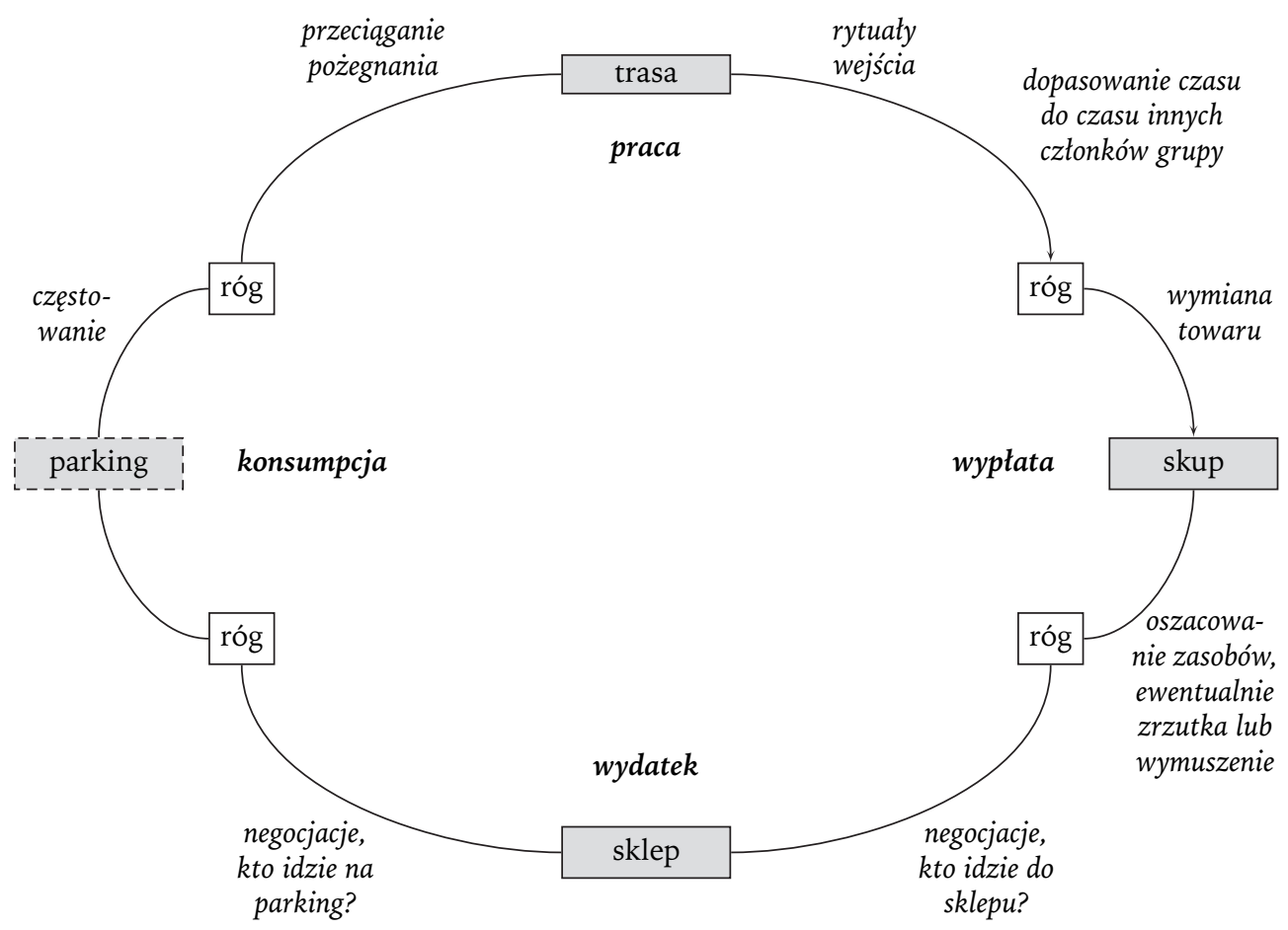

kradzionych), których nie można lub nie opłaca się sprzedawać w skupie: książek, ubrań, staroci, zegarków. Czasem jest to wymiana bardziej osobista, butów czy ubrań przyniesionych z myślą o konkretnej osobie. Na ogół jednak wymieniane są rzeczy na sprzedaż. Przy okazji dyskutuje się o miejscach, w których najlepiej sprzedać dany towar i ile za niego można dostać.

Na rysunku 1 widać także, że nie sposób zakreślić granicy, która oddzielałaby czas wolny od czasu pracy. Niewątpliwie czas pracy to czas „bycia w trasie”, zbierania i ciągłego przybliżania się do skupu. Nie sposób jednak rozstrzygnąć, czy czas spędzany w okolicach skupów jest czasem wolnym. Jest to miejsce uwolnienia się od ciężkiego towaru, miejsce wypłaty, odpoczynku, zaopatrzenia się alkohol, palenia papierosów, spotkania $z$ innymi. Ale jest to także okazja do „zapuszczenia wędki”, „popilnowania samochodu”, dokonania innej transakcji. Trzeba być też czujnym, nie tylko ze względu na okazję do zarobienia, ale trzeba rozglądać się także, czy nie nadchodzą „psy”.

\section{Interakcje i zespół odniesień}

Jak opisałam na przykładzie cyklu czasowo-przestrzennego, w utrzymywaniu spójności grupy bardzo ważną rolę pełnią wymiana i częstowanie. Wymiana 
dotyczy informacji, przedmiotów, drobnych przysług. Przede wszystkim opowiada się o bieżących wydarzeniach dotyczących członków grupy, kto jest na Kolskiej, kto został pobity, co się komu niecodziennego przydarzyło. Wymiana informacji służy dowiedzeniu się, kto gdzie jest, czy ma coś do sprzedania, który z pracowników jest „na skupie”, czy w okolicy kręci się policja.

Częstowanie dotyczy przede wszystkim alkoholu i papierosów. Lojalność wobec grupy stoi tu na ogół w konflikcie z ograniczonymi zasobami. Zwłaszcza jeśli jest więcej osób, osoba częstująca papierosami staje przed niebezpieczeństwem rozdania całej paczki. Butelka wina lub nalewki, niezależnie od tego, kto za nią zapłacił, należy do grupy. Fundator może sobie co najwyżej zastrzec prawo do „ostatniego łyka”. Piwo jest natomiast osobiste, puszki z piwem nie przekazuje się innym członkom grupy, chyba że dwie osoby kupują piwo „na spółkę". Częstowanie jest często wręcz wymuszane. Ponieważ wiadomo, kto i ile dostał „na skupie”, zarobek ten jest uznawany za zasilenie funduszu całej grupy, który natychmiast może być wymieniony na alkohol lub papierosy.

Częstowanie jedzeniem natomiast nie jest częste. Raptem parę razy zdarzyło mi się widzieć, by ktokolwiek z grupy coś jadł. Spożywanie posiłków jest przypadkowe i wynika raczej z okazji niż pory dnia. Nurków spoza grupy widziałam kupujących pieczywo, kawałek wędliny w sklepie spożywczym i jedzących na miejscu. Stali bywalcy raczej polują na okazje, dostarczają ich bufet szkolny, z którego każdego popołudnia wyrzucane jest „świeżutkie” jedzenie, czy „Chińczyk” w jednym z pawilonów. Generalnie o jedzeniu mówi się rzadko, nie słyszałam, żeby ktoś narzekał, że jest głodny.

Spotkania grupy na murku, czy na parkingu są okazją do różnego rodzaju żartów, wygłupów, przyjacielskich złośliwości. Wykorzystywany jest każdy wyjątkowy element, przechodnie, zdarzenie na ulicy. Może być to niecodzienne znalezisko (na przykład petarda), częściej jednak jest to wyśmiewanie się z siebie nawzajem, $z$ tego, kto ostatnio trafił na Kolską, a na ogół żarty z przechodniów i kobiet. Zaczepianie i wyśmiewanie się z innych stwarza poczucie odrębności i spójności grupy. „Wewnętrznymi obcymi”, którzy mogą służyć za przedmiot żartów są kobiety.

Wspólne wartości członków grupy odzwierciedlone są w podobnych marzeniach. Choć nurkowie żyją „z dnia na dzień” i rzadko opowiadają o swojej przeszłości, a jeszcze rzadziej o przyszłości, to z wyrywkowych wzmianek wynika, że największy realnym marzeniem jest „wyrobienie dowodu”. Dowód osobisty jest bowiem uważany za gwarancję otrzymania pomocy w razie potrzeby, uniknięcia kłopotów z policją, daje nawet możliwość wyjazdu za granicę. Niejako wyższym stopniem tego marzenia jest otrzymanie meldunku, który umożliwiłby dostanie legalnej pracy. Otrzymanie dowodu wydaje się jednak równie nierealne, co wygranie w totolotka. Wielokrotnie dyskutowano bowiem o tym, co zrobiono by z wygraną, ale wśród nurków nikt chyba nie kupuje losów. Dwóch nurków zapytałam wprost, co chcieliby robić. Jeden odpowiedział, że chciałby pracować w sortowni surowców wtórnych, „bo się na tym zna”, a poza 
tym „tam płacą trzy tysiące”. Marzeniem drugiego natomiast jest założenie calodobowego skupu na miejscu pustostanu wraz z barem, gdzie sprzedawano by piwo, wino i wódkę na kieliszki.

Nurkowie, którzy wyrażali niezadowolenie ze swojej obecnej sytuacji, uważają, że gdyby tylko przestali pić, ich problemy same by się rozwiązały. Jednocześnie jedyną drogą, którą widzą, by zdobyć więcej pieniędzy, jest zbieranie większej ilości towaru. Ten ambiwalentny stosunek do własnego uzależnienia i możliwości wydostania się z niego dobrze ilustruje dowcip, który opowiedziało mi dwóch nurków.

Jedzie zajaczek przez las swoim nowym mercedesem. Widzi niedźwiedzia, który idzie zataczajac się, $w$ jednej tapie ma alpage, $w$ drugiej szluga. Pyta niedźwiedź zajaca: skąd masz na taki samochód? Kto nie pije, ten ma — odpowiada zajaczek i odjeżdża. Znudzit sie zajaczkowi mercedes, kupit sobie ferrari. Jedzie zajaczek nowym samochodem przez las. Idzie pijany niedźwiedź, $w$ tapie trzyma wino. Zdziwiony, że zając zmienit samochód, pyta: skąd na to masz? Kto nie pije, ten ma — odpowiada zajączek $i$ odjeżdża. Znudzit się zajaczkowi samochód. Kupit sobie helikopter. Lata nad lasem i nagle widzi piękna, ogromna willę; basen, nagie dziewczyny spaceruja, a na leżaku leży niedźwiedź $w$ stonecznych okularach. Zdziwiony zajaczek wyladowat, podchodzi do niedźwiedzia i pyta: skąd na to masz? Sprzedałem butelki — odpowiada niedźwiedź.

Niektóre opowieści z krążących na rogu ulegają wyolbrzymieniu, wypaczeniom, oddziaływaniu stereotypów i urastają do rangi miejscowych legend, choć trudno ustalić, ile jest w nich prawdy. Plotki bywają mniej lub bardziej sensacyjne (na przykład że narzeczony dziewczyny z pobliskiej kamienicy wpadł pod pociąg na dzień przed ślubem) i dłużej lub krócej są przekazywane $z$ ust do ust.

Jednym $z$ takich sensacyjnych wydarzeń, które było szeroko dyskutowane, stał się pożar w pustostanie. Na jego temat uzyskiwałam niespójne informacje. Pierwszy raz dowiedziałam się o spaleniu dzień po fakcie od mieszkańca pustostanu, który powiedział, że pożar wybuchł od niedopałka papierosa. Następnie słyszałam wersję, że w budynku wybuchła butla z gazem. Parę dni później pierwszy raz dowiedziałam się, że było to celowe podpalenie. Pożar wznieciły „okoliczne małolaty”, którym naraził się jeden z dzikich lokatorów. Przez kilka dni, gdy był on w szpitalu, coraz bardziej dramatycznie przedstawiano okoliczności całego zajścia. W opowieściach rosły przewinienia jednej i drugiej strony. Dziki lokator miał nie oddać „małolatom” 20 złotych, które od nich pożyczył; innym razem miał „ganiać za nimi z bejsbolem”. Raz młodzi ludzie mieli go „tylko pobić”, a ogień zaprószyli przypadkowo; to znowu celowo wrzucili butlę $z$ gazem, gdy dziki lokator był na piętrze budynku.

Wygląd i zachowanie starszego mężczyzny, właściciela spalonego pawilonu przy głównej ulicy, spowodowały, że wśród nurków zyskał on przydomek „Żyd”. Jak przekonałam się w rozmowie $z$ samym „Żydem”, krążące na jego temat legendy są zupełnie bezpodstawne. Jego postać pozwala jednak nurkom tłumaczyć różne niezrozumiałe wydarzenia. Na przykład, gdy trzy lata temu spłonął jego pawilon, narodziła się opowieść, że miał tam „tyle złota”. Zaniedbanie 
okolicy uliczki tłumaczone jest: „bo to wszystko jest jego”, „on jest właścicielem całej ziemi tutaj”. „Żyd” całymi dniami przesiaduje w swoim spalonym pawilonie i segreguje nadpalone rzeczy, co pewien czas wynosząc coś do śmietnika na ulicy lub za pawilonami; przy tym na ogół mówi coś do siebie — „modli się", zdaniem nurków.

Wizyta "na skupie” na ogół jest frustrująca, bo nie daje tak wysokiej wypłaty, jak się spodziewano. Pracownicy „nowego” skupu rzeczywiście są niemili dla klientów, a także, jak się sama przekonałam, oszukują „na wadze”. Wyjściu ze skupu towarzyszą więc przekleństwa i narzekania, bo każdy z członków grupy ma poczucie bycia oszukiwanym. Przy okazji w grupie można wyładować frustrację, narzekając nie tylko na pracowników skupu, ale w ogóle na „parszywy świat” i niesprawiedliwość (,ja pracuję, oni zarabiają”). Według nurków, w „nowym” skupie są „dwa zeszyty”, a punkt jest prowadzony przez gang, który $\mathrm{w}$ ten sposób między innymi pierze brudne pieniądze pochodzące ze sprzedaży przemycanego alkoholu. Ich słowa mógłby potwierdzać charakter tej działalności (brak rejestracji, skąd pochodzi większość surowców, co łatwo można wykorzystać zawyżając zysk skupu), skupowanie przez „nowy” skup butelek po markowych wódkach (butelka musi mieć nakrętkę i etykietę) oraz niezwykle luksusowe auta, jakimi przyjeżdżają pracownicy „nowego” skupu.

\section{STOSUNKI MIĘDZY KOBIETAMI I MĘŻCZYZNAMI}

W opisywanej grupie są trzy kobiety. Każda z nich ma też w grupie partnera. Dopiero pod koniec obserwacji zdałam sobie sprawę, że obecności tych kobiet prawie nie widać $\mathrm{w}$ moich notatkach, że $\mathrm{w}$ trakcie spotkań rzadziej się odzywają i prawie nigdy nie są same (choć ich partnerzy tak). Nie zwracałam uwagi na ten aspekt od początku obserwacji, a ponadto moja obecność prawdopodobnie $\mathrm{w}$ dużej mierze zaburzała interakcje $\mathrm{w}$ toku ujawniania się tych relacji, postaram się jednak naszkicować stosunki między kobietami i mężczyznami w opisywanej grupie.

W grupie nie ma kobiet samotnych. Kobieta „przynależy” do mężczyzny. Jest to odzwierciedlone $w$ języku, w miejscu zamieszkiwania, w interakcjach wymiany i częstowania na murku. Na przykład mówi się, że Wiesia to „stara” Andrzeja, ale Andrzej nie jest „starym” Wiesi. Bycie z mężczyzną to dla kobiety zapewnienie sobie bezpieczeństwa i miejsca do mieszkania (nawet jeżeli jest to altanka na działkach). Obserwując grupę doszłam także do wniosku, że pozycja zajmowana w przestrzeni wokół murku nie jest przypadkowa. Stali członkowie grupy, cieszący się największym prestiżem, zajmują pozycje bardziej centralne (rysunek 2). Oni też po prostu dłużej przebywają na murku. Osoby peryferyjne czasami podchodzą tylko na parę minut, zamieniają parę zdań z jednym czy dwoma członkami grupy i odchodzą. W tym układzie kobiety są jakby schowane $z$ tyłu, często też dlatego, że to one siedzą na murku, a mężczyźni stoją. Oznacza to na ogół, że krążąca butelka wina jest podawana kobiecie przez jej 
partnera i jej partnerowi zwracana. Mężczyźni rozmawiają między sobą, komentują przechodniów i przejeżdżające samochody, szturchają się, podchodzą do siebie lub do przechodniów; gdy tymczasem kobiety są z tych interakcji w zasadzie wyłączone, siedząc nieruchomo na murku za ich plecami.

Rysunek 2

Struktura grupy podczas siedzenia na murku

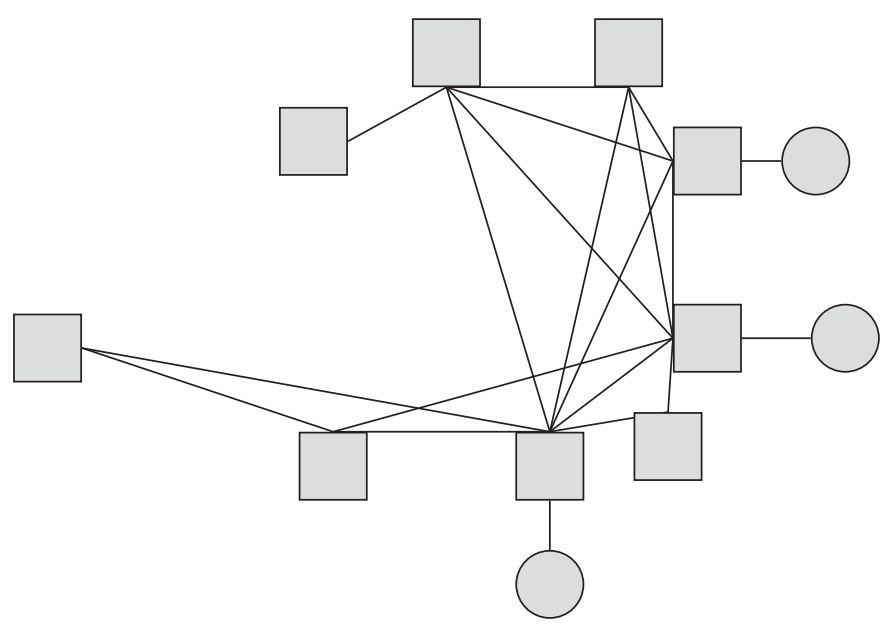

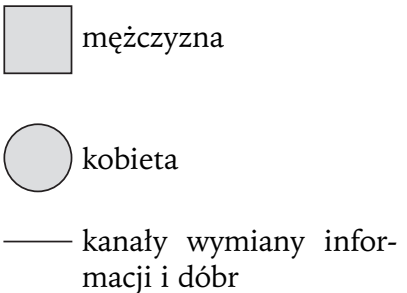

Ci, którzy mają kobiety, zajmują bardziej centralne pozycje

Kobiety są zawsze „na zewnątrz"

Komunikacja i wymiana $z$ kobietami przebiega poprzez ich mężczyzn

Z pary nurków na ogół kobieta delegowana jest z towarem „na skup”. Stosunki między wieloma nurkami a pracownikami „nowego skupu” są wrogie, o czym jeszcze będę pisać. Kobiety deleguje się także do sklepu po alkohol czy papierosy. Z jednej strony można ten zwyczaj interpretować jako wysługiwanie się kobietami, z drugiej natomiast jako próbę unikania konfliktów.

Większy prestiż tych mężczyzn, którzy mają partnerki, może wynikać także $z$ tego, że mogą oni z nich żartować, opowiadać o swoich zrealizowanych lub zamierzonych wyczynach seksualnych. Takie opowieści cieszą się największym zainteresowaniem, są okazją do śmiechu, nawet jeżeli na przykład celowo wykorzystuje się fakt, że partnerka jest upośledzona umysłowo. Ponadto każda wypowiedź kobiety jest pretekstem do skrytykowania jej niewiedzy czy naiwności; każdy żart czy aluzja seksualna może być zilustrowana stosownym gestem lub wymianą spojrzeń między partnerami.

Inną rolę, ale też o seksualnym podtekście, pełnią samotnie przechodzące kobiety, które zaczepia się, na które się gwiżdże, woła: „jaka pani dziś smutna, niech się pani uśmiechnie”; „pani się ze mną ożeni”, lub głośno komentuje się widzialne bądź domniemane przymioty fizyczne przechodzącej. Samotna kobieta jest postrzegana jako przedmiot rywalizacji między mężczyznami. 


\section{GRUPA — KONFLIKT I WSPÓŁPRACA Z INNYMI}

Ponieważ nie sposób oddzielić wewnętrznych interakcji w grupie od interakcji z otoczeniem, część tych stosunków została już nakreślona. Warto natomiast podkreślić, że $\mathrm{w}$ zasadzie żadna $\mathrm{z}$ relacji grupy $\mathrm{z}$ otoczeniem nie jest jednoznacznie negatywna lub jednoznacznie pozytywna. Każda opiera się zarówno na konflikcie, jak i współpracy.

Patrole policji często pojawiają się w okolicach skupów. Kontrolują skupy w poszukiwaniu kradzionego złomu. Sprawdzają też, co dzieje się w pustostanie. Przechodzą przez parking i na tyły pawilonów. Spisują osoby pijące alkohol. Często spisują nurków także pod innym pretekstem, na przykład przechodzenia na czerwonym świetle. Większość z nich zresztą znają z nazwiska, ale mówią do nich po imieniu. Policjanci traktują bywalców rogu także jako źródło informacji, pytają o różne wydarzenia, o osoby poszukiwane. Jednoczesnie pobliska komenda policji wielokrotnie pojawia się $\mathrm{w}$ rozmowach jako ostateczna instancja w potrzebie: „pójdę się tam ogrzać”, „pójdę zapytać, czy mogę się wykąpać”, „tam dadzą mi colę albo kanapkę”. „Psy” traktowane są przez nurków z większym szacunkiem niż strażnicy miejscy, z którymi „nie ma rozmowy”, zaraz wiozą „na Kolską”.

Nurkowie dzielą się na klientów „starego” i „nowego” skupu. Ten podział, $z$ niewielkimi wyjątkami, jest rozłączny. Zdaniem nurków jest to konsekwencja konkurencji między skupami (pracownicy „nowego” widzą, że poszło się raz do „starego” i potem już „nie przyjmują towaru”), ale także $z$ opowieściami krążącymi o „nowym” skupie, co niektórych nurków skłania do bycia lojalnymi wobec „starego". Ten podział jest też spowodowany relacjami między pracownikami „nowego” skupu a nurkami. Jest spora grupa nurków, którzy mają „zakaz wstępu” do „nowego” skupu. Z jednej strony wydaje mi się, że zakaz ten obejmuje najbardziej zaniedbanych nurków, mężczyzn bardzo widocznie nietrzeźwych, upośledzonych psychicznie, którzy mają do sprzedania na ogół tylko makulaturę upchaną w parcianych lub plastikowych workach. $\mathrm{Z}$ punktu widzenia skupu nie są to atrakcyjni dostawcy. $Z$ drugiej strony słyszałam także o kradzieżach dokonanych przez nurków w skupie, za co mają tam zakaz wstępu. Tymi złymi stosunkami tłumaczyłabym także „delegowanie” kobiet „na skup”.

Podczas gdy w „nowym” skupie stosunki są chłodne, jeżeli nie wrogie, nurkowie sprzedają towar i jak najszybciej wychodzą, to w „starym” atmosfera jest zupełnie inna. Stary skup zorganizowany jest też trochę odmiennie. Kontener na makulaturę i kontener na stal stoją w odległości kilkudziesięciu metrów od kantorka, gdzie przyjmowane są puszki i metale kolorowe. Po zważeniu papieru i stali, dostaje się karteczkę i idzie się odebrać pieniądze do kantorka. W sumie w „starym” skupie stale jest co najmniej czterech pracowników. Jednym z nich jest mężczyzna, do którego nurkowie zwracają się „szefu” lub „panie prezesie” i który dla wszystkich jest uprzejmy i lubi wraz z nurkami żartować. W kolejce 
do ważenia towaru panuje przyjacielska atmosfera. Czasami któryś z nurków pomaga pracownikom, na przykład przekładając makulaturę $z$ wagi do kontenera. Nie widziałam, żeby którykolwiek z pracowników „starego” skupu miał jakiś luksusowy samochód, co tak razi nurków w „nowym” skupie. W kantorku „starego" skupu siedzi na ogół „dziewczyna syna szefa”, co dodatkowo łagodzi obyczaje.

Choć nie wszystkie sklepy w okolicy korzystają z obecności nurków, tak jak sklepy alkoholowe i hurtownia papierosów, to wydaje się, że stosunki między pracownikami pawilonów i nurkami na ogół nie są wrogie. Najbliżej murku znajdują się kwiaciarnia i sklep z ubraniami. Kobiety pracujące $\mathrm{w}$ kwiaciarni na ogół tylko uśmiechają się w odpowiedzi na komentarze i zaczepki ze strony nurków. Z kolei właścicielka sklepu z konfekcją to „równa babka, dała mi umyć swój samochód i dała mi za to 10 złotych".

Okoliczne sklepy i lokale stanowią dla członków grupy źródło niewielkich korzyści. Mieszkańcy pustostanu wodę czerpią z "Cepeenu” lub od „Chińczyka”. Na stacji benzynowej można pójść do łazienki, nie słyszałam, żeby nurkowie byli stamtąd przepędzani. Ze sklepu spożywczego, od „Chińczyka” lub z pizzerii można dostać resztki jedzenia.

Przyjaźnie traktują nurków pracownicy sklepów alkoholowych. Byłam świadkiem sytuacji, w której sprzedawczyni, która gdy musiała na chwilę wyjść, najpierw zaprosiła i obsłużyła nurków negocjujących coś przed wejściem. Sprzedawca drugiego sklepu alkoholowego, mimo że w mojej obecności pytał każdego podejrzanego klienta, czy jest trzeźwy i czy aby nie kupuje alkoholu dla nieletnich, to był dla nich zawsze bardzo uprzejmy.

Złomiarze $z$ „wyższej półki”, sprzedający miedź, podjeżdżający do skupu samochodami, czy dresiarze są traktowani z chłodną rezerwą. Mówi się o nich, że to „złodzieje”; o młodych, że „ćpuny” i że zabierają zarobek. Unika się jednak bezpośredniej konfrontacji z nimi. Natomiast nurkowie postawieni jeszcze niżej niż członkowie grupy są przedmiotem drwin, wyzwisk i wymuszania haraczy. Tacy nurkowie to na ogół klienci „starego” skupu i gdy wchodzą w uliczkę, w pośpiechu do niego zmierzają lub w ogóle starają się uniknąć konfrontacji i przychodzą od drugiej strony. Jeżeli już dochodzi do spotkania, "frajerzy”, „lumpy”, „dynksiarze” starają się ignorować wyzwiska bywalców rogu, a gdy znajdą się w strefie bezpośredniej kontroli, wolą oddać 2 złote lub kilka papierosów, niż narazić się na przemoc.

Okoliczna nieletnia młodzież nierzadko zwraca się do nurków z prośbą o kupienie im alkoholu lub papierosów. Jedna osoba $z$ grupy podchodzi do któregoś z mężczyzn siedzących na murku, wręcza pieniądze i za „odpalenie” kilku złotych nurek kupuje im alkohol lub papierosy. Papierosy wręczane są na ogół wprost na ulicy, zaraz po wyjściu ze sklepu. Alkohol częściej jest przekazywany na tyłach pawilonów.

Przypadkowi przechodnie wykorzystywani są przez nurków do wyłudzania jałmużny lub opłaty za „popilnowanie samochodu”. Czasem wymiana ma bar- 
dziej dobrowolny charakter, na przykład sprzedawania w niedzielę gałęzi bzu z działek wiernym wychodzącym z kościoła.

Do grupy mogą należeć niektórzy okoliczni mieszkańcy, tak jak pewien uzależniony od alkoholu i będący na rencie mężczyzna, który z braku innego zajęcia i towarzystwa spędza czas na ulicy. Z mieszkańcami sąsiadującej kamienicy często wchodzą w konflikt dzicy lokatorzy opuszczonego domu, a to z powodu hałasu w pustostanie, a to dlatego, że palą ognisko przed budynkiem. Bezsilni mieszkańcy, którzy zastali poprzewracane swoje pojemniki na śmieci, kierują skargi także do przypadkowych nurków akurat zgromadzonych wokół skupu.

\section{ROZTERKI METODOLOGICZNE}

Moja rola obserwatora-outsidera stwarzała wiele problemów metodologicznych i rozterek etycznych. Początkowo obawiałam się, że nurkowie nie będą chcieli ze mną rozmawiać. Okazało się jednak, że są oni raczej spragnieni kontaktu z drugim człowiekiem, kimś „z zewnątrz”. Podejrzewam, że jako młoda kobieta nie byłam odbierana jako zagrożenie. Zdarzyło mi się jednak spotkać z podejrzliwością, gdy zadawałam konkretne pytania, w szczególności o informacje dotyczące poszczególnych osób - co robią, gdzie mieszkają, byłam posądzona o przynależność do policji. Bardzo szybko stanęłam przed koniecznością wyjaśnienia mojej obecności wokół skupów. Nie starałam się ukrywać swojej tożsamości, ale ponieważ nie przygotowałam jasno sformułowanej odpowiedzi na pytanie, czego dotyczy moje badanie, miałam wrażenie, że w oczach nurków tracę wiarygodność. Moją wiarygodność podważał także fakt, że mimo zapewnień, iż „mam chłopaka”, wciąż samotnie przebywałam w okolicy.

Moja obecność w dużym stopniu determinowała interakcje grupy, zwłaszcza wtedy gdy obecnych było tylko parę osób. Starałam się rozmawiać i uzyskiwać konkretne informacje. Im liczniejsze było zgromadzenie, tym bardziej „przezroczysta" się stawałam i mogłam obserwować mniej zaburzone interakcje. Niewykluczone jednak, że pod moją nieobecność wyglądają one zupełnie inaczej.

Przeszkodą w obserwacji była przede wszystkim rywalizacja o mnie między członkami grupy. Jako samotna kobieta bez przerwy mierzyć się musiałam z komentarzami i propozycjami o seksualnym podtekście lub jawnie seksualnymi. Wielokrotnie zamiast przyglądać się relacjom w grupie, całą uwagę musiałam zaangażować w to, żeby nie dać się zepchnąć w rolę, w której chcieli mnie widzieć mężczyźni, czyli w kategoriach Goffmana (2006, s. 103-106) nie „wypaść z gry". Zakłopotanie zamieniało się jednak niekiedy w poczucie zagrożenia i powstawała konieczność przerwania obserwacji, zerwania interakcji.

Jednocześnie niekiedy podczas rozmów, które przybierały formę opowiadania historii życia, miałam poczucie, że wykorzystuję moich rozmówców, że kupuję ich czas i informacje za parę papierosów, a tak naprawdę nie mogę i nie chcę im pomóc. Tym bardziej dumna byłam, gdy mogłam komuś pomóc w pro- 
sty i niematerialny sposób (popilnować kaloryfera, przetłumaczyć angielską piosenkę); albo gdy w inny sposób czułam się członkiem grupy, co parokrotnie zdarzyło się wobec osób z zewnątrz.

\section{DYSKUSJA Z WYNIKAMI INNYCH BADAŃ}

Na wielu płaszczyznach moje obserwacje zbieżne są z wynikami badań opisywanych w literaturze. Dotyczy to zarówno biografii jednostek, przyjmowanych przez nie ról, jak i interakcji i hierarchii w grupie.

Co prawda, nie było to zamierzonym przedmiotem obserwacji i analiz, ale dostrzegłam, że na poziomie biografii jednostek, o czym już pisałam, zbieranie makulatury i złomu jest najniższym poziomem nędzy i deprywacji oraz poczuciem braku sensu, całkowitym poddaniem się trajektorii (zob. Schütze 1997, s. 27). Pięćdziesięcioletni mężczyzna z województwa dolnośląskiego pisze w swoim pamiętniku: „[kolega] pogodził się z losem, bo pije dzień w dzień za sprzedane butelki, makulaturę lub złom" (Pamiętniki... 2003, s. 348). Moi rozmówcy, gdy zaczynali mówić o sobie, na ogół wskazywali na moment, kiedy „to wszystko się zaczęło”. Na przykład jeden z mężczyzn, tłumacząc się jakby przede mną, dlaczego w ten sposób żyje, zaczął od: „bo ja jestem z domu dziecka". Inny opowiadał o spowodowanym przez siebie wypadku samochodowym, po którym jego przybrani rodzice przestali mu ufać. Mieszkaniec pustostanu $z$ kolei kilkakrotnie opowiadał o tym, jak się zakochał, co doprowadziło go do zdezerterowania $z$ wojska i pociągnęło za sobą kolejne kłopoty.

Analizując historie życia, należy mieć na uwadze ograniczenia metody biograficznej w odniesieniu do bezdomnych. Są to osoby, które „swoją historię” opowiadają wielokrotnie, by wzbudzić współczucie, często także, by otrzymać pomoc od instytucji państwowych lub dobroczynnych. Niezależnie od prawdziwości opowiadanej biografii, bezdomni mogą angażować się w specyficzną "grę" psychologiczną z osobą słuchającą, przez co dystansują się od swojej historii, traktują ją instrumentalnie, potrafią nią manipulować w zależności od potrzeb (Declerck 2004, s. 357 i nast ). Podobny obraz wyłania się z jedynego badania warszawskich nurków Justyny Kaźmierczak (2005).

Wywiady biograficzne $z$ mężczyznami $z$ enklaw nędzy przeprowadziła Agnieszka Golczyńska-Grondas. Na ich podstawie przeanalizowała role społeczne, jakie przyjmują badani mężczyźni. W kontekście badania nurków najciekawsza wydaje się jej analiza roli alkoholika. Rola alkoholika potrafi bowiem zdominować całkowicie wszystkie pozostałe role, a gdy braknie pieniędzy, mężczyźni robią wszystko, by jak najszybciej zdobyć nawet niewielkie sumy: sprzedają znalezione butelki, złom, rzeczy z domu, wyłudzają pieniądze na ulicy, okradają się nawzajem (Golczyńska-Grondas 2004, s. 152). Choć moje obserwacje ograniczały się do momentów, w których badani byli we własnej grupie, nie miałam więc okazji obserwować ich $w$ innych rolach, to - ponieważ nie mają oni rodzin ani domów - wydaje się że ich rola alkoholika, „człowieka 
ulicy”, „nurka” czy „menela” rzeczywiście w większości wyparła wszystkie inne role.

Rytuały związane z piciem wokół skupów bardzo przypominają „spotkania alkoholowe napowietrznych grup" opisywanych przez Rocha Sulimę (2000, s. 106-110). Dotyczy to zarówno „zawłaszczania przestrzeni”, włączania przechodniów do gier grupy, jak i wykorzystywania „rezerwy semantycznej”. Czasowo-przestrzenny rytm dnia osób bezdomnych zaobserwowany wokół skupów przekonująco wyjaśnia Patrick Declerck (2004, s. 29-31) w zbeletryzowanym studium etnograficznym paryskich kloszardów. Twierdzi on, że z racji uzależnienia od alkoholu kloszard musi napić się co 5-6 godzin, co wymusza taki cykl pracy (zdobywania środków) i picia. Cały zarobek kilkugodzinnej pracy jest natychmiast konsumowany, w większości przepijany. Dodatkowo nuda, monotonia i upokorzenie związane z żebraniem (czym para się większość kloszardów) powodują, że nie potrafią oni żebrać dłużej niż 2-3 godziny.

Alkohol umożliwia także „strukturyzację czasu” grupy i ułatwia nawiązywanie przyjaźni i kontaktów seksualnych (Golczyńska-Grondas 2004, s. 153). Taka grupa, która w żaden formalny sposób nie jest wydzielona, a jej członkowie mogą niewiele wiedzieć o sobie nawzajem, została doskonale opisana w klasycznym badaniu dzielnicy Waszyngtonu przez Elliota Liebowa w Tally's Corner. Opisuje on role, które podejmują bohaterowie jego analiz, i pokazuje, że zachowania i strategie stosowane przez mężczyzn z najniższej klasy są calkowicie racjonalne, a osoby te kierują się tymi samymi wartościami, mają takie same potrzeby i marzenia co członkowie klasy średniej (Liebow 1967, s. 65). Stwierdza, że modelem dla nietrwałych i zawodnych związków przyjacielskich są związki pokrewieństwa, dlatego członkowie grupy, a czasem wszyscy Czarni, mówią o sobie nawzajem brother (Liebow 1967, s. 166). Wobec erozji znaczenia rodziny sieć przyjaciół jest szczególnie ważna dla utrzymania poczucia fizycznego i emocjonalnego bezpieczeństwa.

Mimo bardzo ograniczonych zasobów, jakimi dysponują nurkowie, hierarchia, a przede wszystkim utrzymanie wysokiej pozycji w grupie zależy od dzielenia się z innymi. Jest to mechanizm podobny do tego, jaki opisuje William Foote Whyte w klasycznym studium włoskiej enklawy w Bostonie Street Corner Society. W grupie trzeba być hojnym (freespender). Pozycja polega między innymi na tym, że stojący wyżej w hierarchii nie są nic winni stojącym od siebie niżej. Jest to też mechanizm uniemożliwiający funkcjonowanie $\mathrm{w}$ grupie i jednoczesne gromadzenie środków, a więc potencjalne wydostanie się $z$ blędnego koła nędzy. W ten sposób grupa może zachowywać spoistość i zatrzymywać członków przy sobie (Whyte 1943, s. 106-107).

Funkcję podbojów seksualnych i opowiadania o nich analizował Elijah Anderson. Pisał on o grupach ludzi bardzo młodych, dopiero wchodzących w dorosłość, działa tu jednak pewien mechanizm uniwersalny. Ponieważ dla mężczyzn najważniejszą grupą odniesienia są koledzy, to podboje seksualne stają się symbolem statusu. Jest to, zdaniem Andersona (1990, s. 113), wyraz za- 
blokowanych możliwości, braku innych grup odniesienia. W oczach kolegów przechwałki o wykorzystaniu dziewczyny, o braku emocjonalnego zaangażowania są najwyżej cenione.

Elijah Anderson przekonująco opisał też „uliczną etykietę”, zachowania w przestrzeni publicznej, w której wiele osób czuje się zagrożonych. Najważniejszy jest tu opis strategii tych, którzy sami postrzegani są jako zagrożenie: młodych, czarnych mężczyzn w cieszącej się złą sławą dzielnicy Filadelfii. Żeby przełamać obawy przechodniów, starają się oni być uprzejmi i dać do zrozumienia, że nie mają złych intencji. Stąd ich powitania i pytania kierowane do osób nieznanych. Nie obeznani z „uliczną etykietą" Biali często odbierają takie zachowanie jako zaczepne i zagrażające (Anderson 1990, s. 169-172). Być może podobną funkcję pełni zaczepianie przechodniów przez nurków? Przeprowadzenie takiej obserwacji spotkań „meneli” i przypadkowych przechodniów w kategoriach teorii Ervinga Goffmana byłoby moim zdaniem uzasadnione.

Temat bezdomnych kobiet wydaje się w Polsce prawie nie zbadany. Choć niewiele udało mi się zaobserwować i zagadnieniu temu należałoby przyjrzeć się systematycznie, to sądzę, że wyjaśnienia Stacy Rowe i Jennifer Wolch (1990, s. 191-192) z badań nad bezdomnymi kobietami w Los Angeles wydają się warte weryfikacji w polskich realiach. Zdaniem tych autorek, bezdomne kobiety są zmuszane do życia $\mathrm{w}$ parze, ponieważ jest ich mniej niż mężczyzn, a przede wszystkim dlatego, że są narażone na fizyczną przemoc. Ponadto autorki zwracają uwagę na to, że pewne strategie zdobywania pieniędzy, które stosują mężczyźni, wprowadzane w życie przez kobiety mogą być zupełnie odmiennie interpretowane (na przykład młoda żebrząca kobieta może zostać uznana za prostytutkę, albo w każdym razie za osobę gotową do świadczenia usług seksualnych w zamian za pieniądze) (Rowe, Wolch 1990, s. 197).

Wielu członków opisanej przeze mnie grupy wpisuje się w charakterystykę „łaziorów” czy „nurów”, niezależnych od pomocy instytucjonalnej bezdomnych żyjących ze zbieractwa. Nie są to jednak jednostki całkowicie osamotnione. Co więcej, członkowie tej grupy są różnorodni, nie jest to grupa złożona wyłącznie z bezdomnych "łaziorów” ani nie jest to grupa całkowicie wyizolowana $z$ otoczenia. Ich relacje zarówno przemocy czy wykorzystywania, jak i współpracy oraz pomocy należy opisywać w powiązaniu z konkretnym otoczeniem. Chociaż trudno mi się wypowiadać na temat trwałości zaobserwowanych więzi, w czasie moich badań trzon grupy pozostawał niezmienny, podobnie jak związki należących do grupy par. W tym obserwowana przeze mnie grupa byłaby bliższa innym marginalizowanym grupom „żyjącym na ulicy” niż osobom wyodrębnianym ze względu na bezdomność czy sposób zarobkowania.

*

Wnioski $z$ moich obserwacji $\mathrm{w}$ znacznej mierze zbieżne są $\mathrm{z}$ wynikami innych badań, także odległych w czasie i przestrzeni. Dopiero jednak pełny, 
szczegółowy opis może, moim zdaniem, obnażyć istotne różnice i pozwolić na ich głębsze zrozumienie. Funkcjonowanie w grupach osób bezdomnych, w szczególności tych całkowicie poza systemem instytucjonalnej pomocy, moim zdaniem, wymaga ostrożnej obserwacji i opisu etnograficznego.

Wnioski wyciągnięte $z$ obserwacji należy traktować raczej jako wskazówki do dalszych badań niż konkretne ustalenia. Mimo krótkiego okresu obserwacji dostrzegłam, że w obserwowanej grupie pewne wzory zachowań zaczęły się powtarzać, a tworzone w trakcie obserwacji kategorie - wyczerpywać. Nawet moment potencjalnego wytrącenia grupy z codziennej rutyny za sprawą pożaru w pustostanie nie przyniósł zasadniczych zmian.

Hipotezę do weryfikacji w toku dalszych badań sformułowałabym następująco: osoby bezdomne żyjące ze zbieractwa funkcjonują według stabilnych ścieżek czasowo-przestrzennych, przy czym zasadnicze znaczenie ma miejsce skupu surowców wtórnych, w okolicy którego mogą oni łączyć się w pewne grupy. Grupy te zapewniają poczucie przynależności i bezpieczeństwa, wymianę informacji i usług, wspólne spędzanie czasu i rozrywkę. W ramach takich grup wytwarza się hierarchia, w której najniżej stoją niedołężni, najstarsi lub umysłowo chorzy, a poważanie rośnie wraz z siłą fizyczną, zasobami, znajomościami, wyświadczaniem drobnych przysług, hojnością w częstowaniu alkoholem i papierosami, a także posiadaniem partnerki.

\section{BIBLIOGRAFIA}

Adeyemi A. S. i in., 2001, Waste Scavenging in Third World Cities: A Case Study in Ilorin, Nigeria, „The Environmentalist”, t. 21, s. 93-96.

Anderson Elijah, 1990, Streetwise: Race, Class, and Change in an Urban Community, The University of Chicago Press, Chicago-London.

Declerck Patrick, 2004, Rozbitkowie. Rzecz o paryskich kloszardach, tłum. Anna Głowacka, Jarosław Kaźmierczak, Muza, Warszawa.

Goffman Erving, 2006, Rytuat interakcyjny, tłum. Alina Szulżycka, Wydawnictwo Naukowe PWN, Warszawa.

Golczyńska-Grondas Agnieszka, 2004, Mężczyźni z enklaw biedy. Rekonstrukcja petnionych ról spolecznych, Wydawnictwo Uniwersytetu Łódzkiego, Łódź.

Golinowska Stanisława i in., 2007, Praca lekarstwem na biedę $i$ wykluczenie. Strategie wobec pracy. Raport $z$ badań, Instytut Pracy i Spraw Socjalnych, Warszawa.

Grotowska-Leder Jolanta, 2002, Fenomen wielkomiejskiej biedy. Od epizodu do underclass, Wydawnictwo Uniwersytetu Łódzkiego, Łódź.

Hill Ronald Paul, Stamey Mark, 1990, The Homeless in America: An Examination of Possessions and Consumption Behaviors, „The Journal of Consumer Research”, t. 17, s. $303-$ -321 .

Kaźmierczak Justyna, 2005, Życie na peweksie. Bezdomni, bezrobotni, pracujacy..., praca na stronie internetowej: www.bezdomnosc.edu.pl [21.09.2008].

Liebow Elliot, 1967, Tally's Corner: A Study of Negro Streetcorner Men, Little, Brown and Company, Boston. 
Nóżka Marcjanna, 2006, Włóczęgostwo. Zjawisko społeczne i interwencja socjalna, Uniwersytet Jagielloński, Kraków.

Oliwa-Ciesielska Monika, 2006, Piętno nieprzypisania. Studium o wyizolowaniu społecznym bezdomnych, Wydawnictwo Naukowe UAM, Poznań.

Pamiętniki..., 2003, Pamiętniki bezrobotnych. Materiaty konkursowe, prace nagrodzone, oprac. Andrzej Budzyński, Szkoła Główna Handlowa, Warszawa.

Potocka Maria, 2004, Zbieracze, „Niedziela”, edycja kielecka, nr 26; www.niedziela.pl/ artykul_w_niedzieli.php?doc=ed200426\&nr=39 [25.06.2008].

Przymeński Andrzej, 2001, Bezdomność jako kwestia społeczna w Polsce wspótczesnej, Akademia Ekonomiczna w Poznaniu, Poznań.

Rakowski Tomasz, 2007, Między zbieractwem a archeologia. Doświadczenia historii i teraźniejszości wśród bezrobotnych górników wałbrzyskich, „Kultura i Społeczeństwo”, nr 4.

Rowe Stacy, Wolch Jennifer, 1990, Social Networks in Time and Space: Homeless Women in Skid Row, Los Angeles, "Annals of the Association of American Geographers”, t. 80, nr 2, s. 184-204.

Schütze Fritz, 1997, Trajektorie cierpienia jako przedmiot badań socjologii interpretatywnej, „Studia Socjologiczne”, nr 1.

Sulima Roch, 2000, Antropologia codzienności, Wydawnictwo Uniwersytetu Jagiellońskiego, Kraków.

Sytuacja..., 2005, Sytuacja osób bezdomnych w Warszawie - opinie osób bezdomnych $i$ pracowników socjalnych. Raport CBOS, Warszawa.

Tevera Daniel S., 1994, Dump Scavenging in Gaborone, Botswana: Anachronism or Refuge Occupation of the Poor?, „Geografiska Annaler”, t. 76B(1), s. 21-32.

Wachowiak Piotr, 1998, „Kryminalistyczne aspekty przestępczości bezdomnych”, Uniwersytet im. Adama Mickiewicza (praca magisterska).

Whyte William Foote, 1943, Street Corner Society: The Social Structure of an Italian Slum, The University of Chicago Press, Chicago.

Wódz Kazimiera, 1992, Podejście antropologiczne we wspótczesnej socjologii miasta, w: Kazimiera Wódz, Krzyszof Czekaj (red.), Szkoła chicagowska w socjologii. Tradycja myśli społecznej $i$ wymogi wspótczesnej socjologii empirycznej, Uniwersytet Śląski-PTS, Katowice-Warszawa.

\section{EVERYDAY LIFE ROUND THE SCRAP YARDS IN WARSAW}

\section{Sum mary}

This paper explores the survival strategies, daily-paths and everyday activities of a group of homeless men in Warsaw who live by scavenging. It is based on data collected during three months (April-June 2008) of participant observation focussed on a street corner in the vicinity of two recycling centres/scrap yards, where a group of waste-picking men after selling the scavenged goods meet and hang out on a daily basis. The place performs multiple functions and is a central point both in their daily-paths, their time-organizing framework and their functioning in a group.

\section{Key words/słowa kluczowe}

waste scavenging / zbieractwo; homelessness / bezdomność; time-space paths / ścieżki czasowo-przestrzenne; groups / grupy 